\title{
Wittgenstein, medicine and neuropsychiatry
}

\author{
Hélio A.G. Teive' , Guilherme Ghizoni Silva², Renato P. Munhoz ${ }^{1}$
}

\begin{abstract}
A historical review is presented of the link between Ludwig Wittgenstein, considered the most important philosopher of the $20^{\text {th }}$ century, and medicine, particularly neurology and psychiatry. Wittgenstein worked as a porter at Guy's Hospital in London, and then as a technician at the Royal Victoria Infirmary in Newcastle. He wrote about his important insights into language, and neuroscience. It has been suggested that he had Asperger syndrome and a possible movement disorder (mannerisms).
\end{abstract}

Key words: Wittgenstein, philosophy, neurology, psychiatry.

\section{Wittgenstein, medicina e a neuro-psiquiatria}

\section{RESUMO}

Uma revisão histórica sobre a ligação entre Ludwig Wittgenstein, considerado um dos mais importantes filósofos do século XX, e a medicina, a neurologia e a psiquiatria é apresentada. Ludwig Wittgenstein trabalhou como porteiro no hospital Guy, em Londres e depois como técnico na Royal Victoria Infirmary em Newcastle, no Reino Unido. Ele escreveu importantes insights sobre linguagem e tem sido sugerido que ele tinha a síndrome de Asperger, e possivelmente um distúrbio do movimento (maneirismo).

Palavras-chave: Wittigenstein, filosofia, neurologia, psiquiatria.

Neurosciences, and neurology in particular, have progressed significantly in recent years and have divided into a growing number of sub-specialties, including more recently the discipline known as neurophilosophy ${ }^{1,2}$.

Neurophilosophy considers the hypothesis that the "mind", as it is called, essentially represents the level of brain activity. Thus the crucial mind-body problem and other important issues such as consciousness, free will and the nature of knowledge are fundamental to the study of neurophilosophy ${ }^{1,2}$.

Ludwig Wittgenstein was one of the several philosophers whose work was related to neurosciences, and neurology in particular.

Here we review the links between Wittgenstein and medicine and neuropsychiatry from a historical perspective.

\section{Ludwig Wittgenstein}

The Austrian philosopher Ludwig Wittgenstein has won a place in history as one of the most important philosophers of the $20^{\text {th }}$ century (Figure).

He was born into one of Vienna's wealthiest families on $26^{\text {th }}$ April 1889 and died in Cambridge on $29^{\text {th }}$ April $1951^{3}$.

His family was originally Jewish, but his grandfather became a Protestant and Wittgenstein was baptized as a Catholic ${ }^{3}$.

Wittgenstein was home educated up to the age of 14 . He then moved to Berlin to study engineering. In 1908 he went to Manchester University as a research student in the department of engineering. His initial interest was in aeronautics but changed to mathematics and then to the philosophical basis of mathematics. In 1911 he moved to Cambridge to study philosophy under Bertrand Russell. In a
Hélio A.G. Teive

Rua General Carneiro 1103/102 80060-150 Curitiba PR -Brasil

E-mail: hagteive@mps.com.br

Received 22 April 2011 Accepted 29 April 2011
${ }^{1}$ Neurology Service, Internal Medicine Department, Hospital de Clínicas, Federal University of Paraná, Curitiba PR, Brazil; ${ }^{2}$ Postgraduate Program, Department of Philosophy and Methodology of Sciences, Federal University of São Carlos, São Carlos SP, Brazil. 


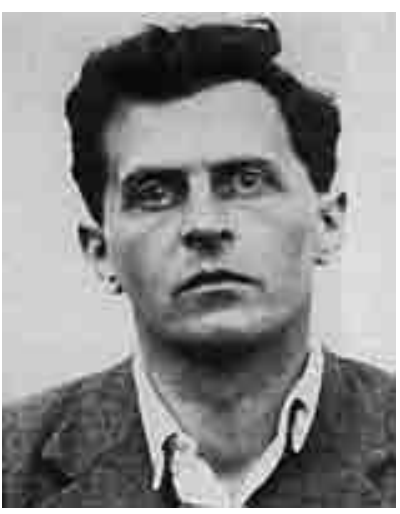

Extracted from Google Images: dannarhitec wordpress.com.

Figure. Ludwig Wittgenstein

famous incident Wittgenstein asked Russell, "Do you think I am an absolute idiot?" To this Russell answered, "Why do you want to know?" Wittgenstein replied, "Because if I am I shall become an aeronaut, but if I am not I shall become a philosopher.",3,

Russell soon became Wittgenstein's most important interlocutor and he was also the target of his fiercest criticisms.

Most of his life he worked in Cambridge, where he studied for his $\mathrm{PhD}$ and taught philosophy after $1939^{3}$.

Wittgenstein's ideas had a profound impact on many areas of philosophy, such as philosophy of language, mathematics, psychology, ethics, aesthetics, and science $^{3-5}$.

\section{Wittgenstein at Guy's Hospital}

With the outbreak of the second World War in 1939, Wittgenstein, then Professor of Philosophy at Cambridge, left the university. While there is no reliable information about his whereabouts in the following two years, in 1941 he became a porter at Guy's Hospital in London".

Henderson, in an article on Wittgenstein's period, as a porter at Guy's Hospital, stated that, "Hospital porters are not, as a rule, a group of people noted for their intellectual achievements. So it is a matter of interest when the man who is professor of philosophy at Cambridge, and probably the most influential philosopher of his time, becomes a hospital porter."

There is a wealth of interesting information about the 2-3 year period Wittgenstein spent at Guy's Hospital. One anecdote involves a hematologist at the hospital, Dr R. L. Waterfield, who was also an amateur philosopher, who eventually recognizing Wittgenstein. On being recognized, Wittgenstein said, "Good God, don't tell anybody who I am." .

During his stay at Guy's Hospital Wittgenstein apparently produced the finest quality zinc oxide ointment ${ }^{4}$.

Wittgenstein subsequently started to help Dr. Grant and Dr. Reeve, who were working on wound shock for the Medical Research Council (MRC), and when the MRC unit left Guy's Hospital for the Royal Victoria Infirmary in Newcastle, Wittgenstein went with them as Grant's technician".

\section{Wittgenstein at the Royal Victoria Infirmary}

Wittgenstein made use of his engineering skills in the MRC unit at the Royal Victoria Infirmary, including producing frozen cuts and paraffin sections $s^{4}$.

He also invented a new device that improved the way pulse pressure was recorded, aiding the investigation of pulsus paradoxus (diminished pulse pressure during respiration) in rats . $^{4}$

In 1944, when the MRC unit was transferred to Italy, Wittgenstein stayed in Newcastle, working until the end of the war, when he returned to Cambridge ${ }^{4}$.

\section{Wittgenstein and language}

Wittgenstein's main contribution to philosophy was in the field of philosophy of language. All the other topics dealt by him were addressed from the point of view of the analysis of language. Even his philosophical method was based on language, as the thesis that philosophical problems were pseudo-problems resulting from misunderstandings regarding the logic of our language. This led him to a therapeutic perspective, in which the aim of philosophy is the disentanglement of the conceptual knots, resulting from the use of language in disarray with grammar ${ }^{5,6}$.

\section{Wittgenstein and neuroscience}

As explored by Bennett and Hacker, Wittgenstein's ideas, even though they do not address neuroscience directly, can provide many interesting insights into its conceptual foundations ${ }^{7}$. One important insight is the criticism of the attempt to escape Cartesian dualism by ascribing psychological attributes not to the mind, but to the brain or parts of the brain. In such cases, it has been said that the brain believes, interprets, knows, reasons, has experiences, and so on ${ }^{7}$. Another important Wittgensteinian insight that has bearings on the philosophical foundations of neuroscience is the so called "private language argument"

\section{Wittgenstein and Asperger syndrome}

Biographical accounts describe behavioral changes in Wittgenstein that meant he had great difficulty with social relationships ${ }^{3,4}$.

An example is the famous quarrel with the philosopher Karl Popper in Trinity College, Cambridge, in 1946, in which Wittgenstein picked up a poker from the fireplace and waved it at Popper in a seemingly threatening manner ${ }^{3}$. 
Many researchers have diagnosed Wittgenstein's behavioral changes with a wide range of hypotheses: schizoid personality, schizophrenia and Asperger syndrome $\mathrm{e}^{3,4,8}$.

An article in 2000 suggested that Wittgenstein had the major features of Asperger syndrome ${ }^{8}$. He had a severe impairment in reciprocal social interaction, a lack of appreciation of social cues and emotionally inappropriate behavior. Others suggested features were repetitive adherence, the imposing of routines, speech and language problems and non-verbal communication problems (limited facial and inappropriate expressions and a peculiar stiff gaze $)^{8,9}$.

Affective disorder (depression) is another feature commonly associated with Asperger syndrome and one frequently observed in Wittgenstein, in whom it was sometimes accompanied by thoughts of suicide ${ }^{3,8,9}$.

\section{Did Wittgenstein have a movement disorder?}

Dawkins' book "A Devil's Chaplain" describes an interesting case involving one of his students who had a habit of closing her eyes tight, dropping her head to her chest and remaining motionless in this position for around 30 seconds before answering difficult questions ${ }^{10}$. He discovered that the student's habit was similar to that of her parents, who were admirers of Wittgenstein. The philosopher added, "But that's Wittgenstein!" ${ }^{10}$. This suggests that Wittgenstein may have had a mannerism - defined as a pathologically altered form of ritualized behavior - that was imitated by his admirers ${ }^{10}$.

\section{Wittgenstein: the final disease}

The years until his death in 1951 were marked by a period of poignancy ${ }^{3,4}$. His health deteriorated, initially with complaints of asthenia and exhaustion ${ }^{4}$. He underwent several medical examinations and extensive workups in the UK and the USA, all of which were neg- ative. Finally, he was examined again in Cambridge and found to have carcinoma of the prostate and was treated with radiotherapy. He died at home, and his last words were, "Tell them I have had a wonderful life.",".

\section{Conclusion}

From a porter at Guy's Hospital in London, as a technician at the Royal Victoria Infirmary in Newcastle to becoming one of the most important philosophers of the 20th century, Ludwig Wittgenstein developed several connections with medicine, neurology and psychiatry during his life. Finally, it has been suggested that he had Asperger syndrome and a possible movement disorder (mannerisms).

ACKNOWLEGDMENTS - The authors thank Prof. Josemir W. Sander, from UCL, Institute for Neurology, University College London, UK, and Prof. Luís dos Ramos Machado, from Department of Neurology, Hospital das Clínicas, São Paulo University Medical School, São Paulo, SP, Brazil, for their kind revision of this manuscript.

\section{REFERENCES}

1. Churchland PS. Neurophilosophy: the early years and new directions. Funct Neurol 2007; 22: 185-195.

2. Lunstroth J. No strangers: medicine, neuroscience, and philosophy. Am J Bioeth 2008; 8: 59-61.

3. Monk R. Ludwig Wittgenstein: The duty of genius. Penguin Books, New York, 1990.

4. Henderson JR. Ludwig Wittgenstein and Guy's Hospital. Guy's Hosp Rep 1973; 122: 185-193.

5. Wittgenstein L. Philosophical investigations. Blackwell Publishers, Oxford, 1953.

6. Timmons $\mathrm{S}$. Wittgenstein's language games as a theory of learning disabilities. Nurs Philos 2006; 7: 20-22.

7. Bennett MR, Hacker PMS. Philosophical foundations of neuroscience. Blackwell Publishers, Oxford, 2003.

8. Fitzgerald M. Did Ludwig Wittgenstein have Asperger's syndrome? Eur Child Adolesc Psychiatry 2000; 9: 61-65.

9. Toth K, King BH. Asperger's syndrome: diagnosis and treatment. Am J Psychiatry 2008; 165: 958-963.

10. Dawkins R. O capelão do diabo. Companhia Das Letras, São Paulo, 2003: 13-214. 